\title{
REVIEW
}

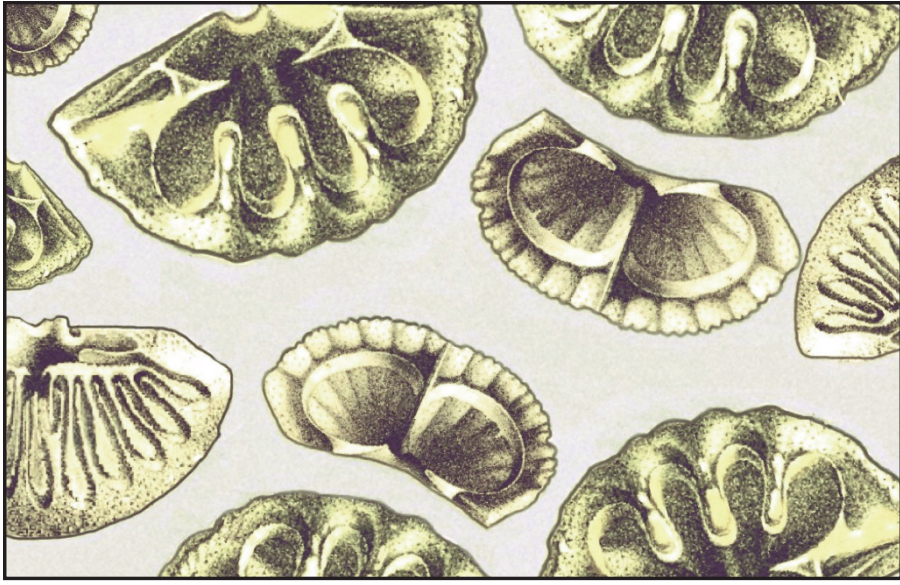

\section{EDUARD SUESS GEOLOGIST: Catalogue of the Exhibition}

\section{Professor Dr. Dr. h. c. mult. A.M. Celâl Şengör}

İstanbul Technical University (2015)

Istanbul, Turkey, 76 p.

5 Turkish Liras (plus shipping); Softcover

Forpurchase,e-mail:Dr. Celallşengör(sengon@itu.edu.tr)

after 30 Soptember 2015

Electronic version available free

\section{Reviewed by Bruce Ryan}

Geological Survey of Newfoundland \& Labrador

Department of Natural Resources

Box 8700, St. John's

Newfoundland-Labrador, A1B 4J6, Canada

E-mail:bruceryan@gov.nl.ca

This neat little book, containing less than eighty pages and profusely illustrated, is a compilation of selected material about the great Austrian geologist Eduard Suess (1831-1914), celebrating his lifetime of contributions to geoscience and his country. The book is a catalogue and explanatory commentary to accompany a recent (April 17 to May 11, 2015) exhibition saluting Suess' exemplary life, displayed at the Cultural Office of the Austrian Consulate-General in Istanbul, Turkey. The author, Dr. Celâl Şengör, contributed the exhibit material from his own library. Şengör clearly admires Suess and cherishes the manuscripts and other items he has in his collection. I wish I had seen the actual exhibit and been further enlightened by Dr. Şengör!
Dr. Celâl Şengör is a world-renowned geologist whose writings include many articles that show his passion for those who founded the tenets upon which current geological thinking rests. One of his heroes is clearly Eduard Suess. The respect and admiration Şengör has for Suess shine in this book and in two more substantial papers published in Geoscience Canada (Vol. 42, no. 2, p. 181-246) and the Austrian Journal of Earth Sciences (Vol. 107, p. 6-82). Şengör expresses great regret that so few geologists appreciate the influence that the fertile mind of Suess had upon our science, and he is determined to correct this educational deficiency. He sheds light on the life of this remarkable man, and leads us through the perceptive observations that steered Suess to contemplate how the patterns of land and sea came to be. Suess was a scientist who, in the modern vernacular, was 'thinking outside the box.'

Let me tell you how I first came to know the name of Eduard Suess. One of my undergraduate textbooks, A.O. Woodford's Historical Geology, recounted how Suess had used the Glossopteris flora to add South America to the other land masses (Africa, Madagascar, India, Australia) he had already amalgamated into his recently christened supercontinent of Gondwanaland. I came upon his name again in Elements of Structural Geology, where E. Sherbon Hills credited Suess' monumental tome Das Antlitz der Erde (The Face of the Earth) as the pioneering study of the large scale tectonics of continents and oceans. I gained a sense that this man was a thinker on a grand scale, yet he seemed to be relegated to 'asides' in our courses and many other texts. He was re-introduced to me in grad school by the late Bob Stevens, and my interest was rekindled when I later collected geologically-themed postage stamps, because Suess' image appeared on an Austrian stamp. With the publication of Şengör's book and the companion pieces noted above, Eduard Suess should now be elevated to his rightful position among the giants of geology, and recognized for many other contributions.

Reviewing a publication dedicated to an exhibit of antiquarian objects is daunting, because descriptions cannot be directly associated with tangible artifacts. The reader, and the reviewer, have to imagine 'being there and seeing that' on the basis of illustrated guides such as this one. This illuminating and informative volume of archival research meets this objective ... and far more than this. The body of the text is divided into chapters that address specific facets of Suess' professional, personal, and political life. I must admit that I am a biased reader, because a love of history was instilled in me in grade school and a love of geology was nurtured at university. So, when the two are combined, my eyes light up and my mind drifts back in time in more ways than one!

In the 'Introduction' Şengör awards Suess the distinction of being "probably the greatest geologist who ever lived" and 
then proceeds to summarize the great man's geological accomplishments and his humanitarian contributions. We are first introduced to Suess' masterpiece Das Antlitz, der Erde (The Face of the Earth), a synthesis of world tectonics described as "the greatest book in the history of geology". In the 'Life and Family' chapter, Sengor focuses on Suess' personal side, giving us a glimpse into his forebears, along with pivotal events in his upbringing and education. A chapter entitled 'First Studies' documents some of Suess' early work, and tells us how geology became Suess' passion when he lived in Prague in the mid1800s. Şengör marvels, as should the reader, at Suess' capacity to comprehend and synthesize, as a teenager, the voluminous geological literature needed for his first scientific publication a few pages in an 1851 tourist guidebook to the spa town of Karlsbad. The chapter also recounts how Suess developed an interest in graptolites, sent his findings to Joachim Barrande, but was seemingly 'scooped' by Barrande! In spite of this scientific impropriety, Suess eventually brought his findings to the palaeontological community, even applying Barrande's taxonomy to the graptolites. The chapter entitled 'Palaeontological Studies' deals with Suess' dedication to studying fossils, especially brachiopods. Immaculate line drawings reproduced here from some of these publications show not only his observational depth but also his artistic talent. In this age of pixels and polygons it is all too easy to overlook the painstaking pen work that went into such superb illustrations. His palaeontological contributions, which continued for nearly another fifty years, made him a 'household name' among his contemporaries in France and England. A chapter entitled 'Studies on Urban Geology: Foundation of Urban Geology' gives the reader a look at the 'practical geology' side of Eduard Suess and shows how his grasp of engineering served the city of Vienna. His insights went far beyond geology, as demonstrated by his suggested cure for a typhoid outbreak - bring in fresh drinking water! His 1862 book about the geological aspects of Vienna led to his election to the city council, heralding 30 years of political activism. The references to him as a "mad" driver behind the city's late 1860s decision to construct a system of mammoth aqueducts to bring fresh water from the Alps are a teaser for more reading about this largely unknown side of his career.

The book next returns to Suess as a 'traditional' hard-rock geologist, giving a record of his influential work in 'Stratigraphic Studies.' This chapter reveals how his insights into sea-level fluctuations led him to propose the former existence of a major water body across central Europe and part of Asia, now referred to as the Para-Tethys Sea. These studies also led him to contemplate the mechanism of global sea-level changes. Suess' documentation of abrupt changes in the fossils associated with differing depositional environments steered him to the conclusion that Charles Darwin's theories did not give enough weight to variations precipitated by environmental fluctuations. He also came to an astute conclusion about Alpine structure: the igneous rocks of the southern Alps were deformed along with their sedimentary envelope. Clearly, the prevailing idea that the igneous rocks were responsible for Alpine mountain building could not be correct. His interest in tectonic studies was born, and is explored further in the next chapter, 'The Beginning of Suess' Tectonic Studies,' which provides a fascinating glimpse into his rapid evolution from a local expert to a global thinker. His studies of a simple anticlinal structure in salt mines near Krakow in 1868 soon led to the recognition that this same structure extended along the entire Alpine front. He went on to propose that such folds were a consequence of large-scale horizontal movements of the Earth's crust and that this motion was likely the dominant force in mountain building. His 1873 ruminations on "slow and heterogeneous motion" of the entire surface of the Earth as being the instigator of worldwide mountain ranges, made evident in Şengör's English translation of the obscure original German summary of the paper, underscores how Suess' prescient analysis set the stage for what would eventually present itself as plate tectonics, although he viewed thermal contraction of the surface as the driving mechanism. Sengör highlights Die Entstehung der Alpen (The Origin of the Alps) as expounding hypotheses that "inaugurated the modern era" of global tectonic studies; it is, indeed, a window into the mind of a geologist who viewed the whole Earth as a dynamic and intertwined physical and biological system. A chapter entitled 'Tectonic Studies' further explores these ideas, especially as developed in his colossal, five-volume treatise Das Antlitz, der Erde (The Face of the Earth) published between 1883 and 1909. It specifically highlights Suess' rejection of many of the outdated notions of the times. He embraced the uniformitarian views of Charles Lyell and James Hutton, and his views of the Earth spanned the scale from hand specimen to mountain range to continent. Here, we first encounter Suess' proposal that the closure of the Tethys Ocean was responsible for the formation of the imposing mountains of the AlpineHimalayan chain. We are also reminded of Suess' belief that fluctuations in the volumes of water in the world's oceans caused worldwide regressions and transgressions seen in the geological record. Șengör comments on some notions that have stood the test of time, as well as others that have collapsed under the weight of more recent geological interpretations. Although appropriate for an exhibit guide, this synthesis is a far-too-brief overview of Suess' tome, considering the treatment afforded other aspects of Suess' professional and personal life. Fortunately, those who want more can easily find it in Şengör's complementary treatment of Suess in the recent Geoscience Canada and Austrian Journal of Earth Sciences articles.

Suess, it seems, also had a very pragmatic side. A short discussion of his role in economic geology and of the importance of his views on gold and silver to finance is presented in a chapter entitled 'Monetary Politics and the Valuable Metals.' He penned two books on the topic of metals in relation to monetary systems, one dedicated to gold and the other to silver, and served as a consultant to the governments of several countries. A chapter entitled 'The Last Scientific Writings of Suess' is dedicated to four papers postdating the completion of Das Antlitz der Erde. The earliest of these was a 1909 summary dealing with the evolution of life relative to the environmental effects of the biosphere. Contributions on the history and philosophy of science and the physical and historical aspects of the Danube River demonstrate that his breadth of study did not diminish with age. Suess' very last paper, on the forces responsible for mountain building, receives a series of interesting queries from Şengör, who wonders why this 1913 publication makes no mention of Alfred Wegener's newly minted concept of continental drift and laments the fact that 
we will never know the reasons for its omission! The final chapter returns to Suess as 'The Politician,' recounting his enormously important civic contributions. He was not, in some cases, averse to tackling the oftentimes sensitive issue of the relation between church and state. The final paragraph expresses his desire to remain a 'man of the people,' avoiding political accolades and titles, and the 'Epilogue' further emphasizes his indifference to glorifying monikers and worldly goods. He preferred to live a life that at its close was marked by "a tranquil conscience and an innerly cheerful spirit." Here, Celâl Șengör challenges us to emulate this man of modest means who came to the end of his geological and political journey at his residence in Vienna on April 26, 1914.

The layout of this little book is quite pleasing, especially in its abundance of colour illustrations of items from the exhibit, and I detected very few printing glitches. Given the wealth of illustrative material, the many publications cited, and the need to cross-reference from place to place and time to time, a few misconnections are almost inevitable. For example, a couple of figure captions are misplaced, and scattered typographical errors are apparent. There are a couple of references to items that could have been appreciated only by attending the exhibition, and their inclusion seems extraneous without illustration. The rendering of some material - such as large maps - for the printed page is in places plagued by very fine and/or fuzzy and/or indecipherable print, but these challenges are also to be expected. Even if all detail cannot be resolved, the reader can grasp the significance of such material when crossreferenced to the text. The minor blemishes can be overlooked, and they do not seriously overpower or detract from the narrative and the overall appearance of the book. Unlike the multilingual Celâl Şengör, most of us cannot read the illustrated papers in their original script, and Dr. Şengör has provided yeoman service for us all, with his careful translations and allied commentary.

Overall, this book is delightfully enlightening and readable. At 5 Turkish Liras, it is a bargain for geological history buffs, and it will give you unforgettable insight into a very perceptive late $19^{\text {th }}$ and early $20^{\text {th }}$ century scholar of the Earth sciences. The text and illustrations constitute history, geology and politics all rolled into one, but the reader must remember that the book's contents and layout reflect its original purpose - a guide to an exhibit. Despite such limitations, it is a concise story of a champion of our science and an incredible man. Celâl Sengör is to be congratulated and praised for his initiative in organizing and curating the exhibit and for bringing the profound thinking of this remarkable geologist to an audience that would otherwise not be aware of Suess' contributions to the foundations of tectonics and his beloved Austria. Şengör characterizes him as an 'admirable idol,' and deservedly so. Having past and contemporary idols was par for the course when I was immersed in university geology studies decades ago, but nowadays I get strange looks when I inquire of such among students and neophyte geologists because they are largely oblivious to the science's great 'movers and shakers.' This book is a reminder that as we look up in awe at the world's great mountain ranges and contemplate their origin, we should also look down because we are 'standing on the shoulders of giants,' like Eduard Suess who decades ago pondered the same questions.
I will end this review with one last personal note, harking back to my own time at Memorial University in St. John's during the heady days when global plate tectonics became a new paradigm for Earth dynamics. We keenly absorbed the ideas of our own great Appalachian geologist and continental drift advocate, Harold ('Hank') Williams, and briefly rubbed shoulders with John Dewey, Jack Bird, Maarten de Wit and a host of other enthusiastic proponents. After reading this book, I cannot help but see Suess in the same light as the lately departed Hank - both were mega-thinkers who moved continents (albeit in different ways!) to make mountains. I can imagine them now excitedly debating their principles and tectonic mechanisms 'on the Other Side.' So, I unreservedly encourage you to make room for this little book in your bookcase, even if you have to move mountains of other ones to do it! 